\title{
John Caldwell Calhoun - dylematy politycznych wyborów
}

Rozważania w niniejszym artykule chciałabym rozpocząć od przedstawienia postaci Johna Caldwella Calhouna. Jest to konieczne, gdyż w polskiej historiografii nie ma żadnej pracy mu poświęconej. Przez długie lata również historycy amerykańscy starali się raczej o nim nie wspominać, gdyż po wojnie secesyjnej nie wypadało mówić ani o stanowych partykularyzmach, ani o prawach stanowych, a ci politycy, którzy nie aprobowali federalnej polityki państwa, byli usuwani w cień zapomnienia ${ }^{1}$. Ta kontrowersyjna, raczej negatywnie kojarzona, postać zasługuje jednak na przypomnienie i uwagę.

John Caldwell Calhoun pochodził $z$ Południa, a dokładniej z Południowej Karoliny. Urodził się pod koniec wojny o niepodległość w leżącym w jej zachodniej części Dystrykcie Abbeville 18 marca 1782 r. ${ }^{2}$ Jego rodzice Patrick i Martha byli szkockoirlandzkimi kalwińskimi prezbiterianami. Rodzina Calhounów pojawiła się na amerykańskiej ziemi w 1733 r. i osiedliła się w zachodniej części Pensylwanii. Kalwiński rodowód jest o tyle ważny, że „zakorzenił" on w swych wyznawcach przekonanie, że byt jest walką przeciwko złu. Na własnej skórze doświadczał tego Patrick

${ }_{1}$ Biogram zawarty na stronach amerykańskiego Kongresu jest enigmatyczny. Czytamy tam, że Calhoun, kuzyn Johna Ewinga Colhouna i Josepha Calhouna był "Representative and a Senator from South Carolina and a Vive President of the United States..." Dalej wymienione sa etapy jego nauki i kariery politycznej. Por. http:// bioguide.congress.gov/scripts / biodisplay.pl?index=C000044.

2 Krótki biogram Calhouna por. Encyklopedia historii Stanów Zjednoczonych Ameryki (Od Deklaracji Niepodległości do współczesności), red. A. Bartnicki, K. Michałek, I. Rusinowa, Warszawa 1992, s. 44-45. 
Calhoun, zaznając trudnego życia na pograniczu, gdzie często dochodziło do walk $z$ Indianami. Dlatego też rodzina przeniosła się dalej na zachód, za pasmo gór, do Augusty położonej w dolinie Shenandoah. Nie zagrzali tam zbyt długo miejsca, przenosząc się do New River w południowo-zachodniej Wirginii, następnie do Waxhaws na granicy Karoliny Północnej i Południowej. Tam usłyszeli opowieści o bogatych ziemiach, które brytyjska Korona uzyskała od plemienia Cherokee. Leżały one ponad 100 mil na zachód - w Południowej Karolinie. Rodzina Calhounów dotarła tam w 1756 r. i osiedliła się w rejonie Long Canes Creek ${ }^{3}$.

Ojciec, człowiek o surowych zasadach, został znaczaca postacią w miejscowej społeczności. Walczył w wojnie „Z Francuzami i Indianami”. Był sędzia, geometra i członkiem stanowej legislatury. Brał czynny udział w wojnie o niepodległość, ponadto sprzeciwiał się bogatym grandom $z$ Charlestonu, popierając farmerów $z$ zachodu. Nie uznał federalnej konstytucji, gdyż uważał, że zbyt silna władza federalnego rzadu nazbyt ogranicza poczucie wolności.

Powróćmy jednak do jego syna Johna Caldwella. Początki jego nauki były typowe dla społeczności południowych kolonii. Podstawy pisania, czytania i arytmetyki poznał w lokalnej szkole, będącej $\mathrm{w}$ istocie chata $\mathrm{z}$ drewnianych bali (log-cabin school). Następny etap nauki (od 1795 r.) przypadł na szkołe prowadzona przez jego szwagra Mosesa Waddela ${ }^{4} \mathrm{w}$ stanie Georgia. Tam znacznie poszerzył swą wiedzę, choć tak naprawdę szkoła ta wówczas bardzo straciła na znaczeniu 5 . Mimo to John sam uzupełnił swe wykształcenie. Przeczytał wówczas prawie wszystkie książki z biblioteki szwagra. Można uznać, że było to intelektualne przebudzenie Calhouna. Wysiłek ten przypłacił jednak zdrowiem. $Z$ uwagi na znaczne osłabienie został ze szkoły odebrany przez matkę. Nie było to jedyne nieszczęście, jakie spadło na rodzinę. W tym samym czasie zmarł jego ojciec. Dlatego młody John był bardziej potrzebny na farmie niż w szkole u szwagra. Przez pięć lat orał ziemię, okopywał i zbierał bawełnę. Nauczył się wówczas zarządzania farmą, a ciężka praca korzystnie wpłynęła na jego zdrowie i tężyznę fizyczną. Po

3 Historię rodziny Calhounów por. Ch.M. W il t s e, John C. Calhoun Nationalist, 1782-1828, Indianapolis 1944.

4 Por. John C. Calhoun. A Disquisition on Government and Selections from the Discourse, ed. C. Gordon Post, New York 1953, s. VIII, gdzie autor wstępu nic nie wspomina o kilkuletniej przerwie w nauce.

5 „He received a strict classical education”. Cyt. za: ibidem, s. VIII. 
latach docenił tę szkołę życia. Podobno lokalna społeczność uważała, że John „powinien być wykształcony”. W 1800 r., ulegając namowom swego starszego brata Jamesa, który zaproponował, że zajmie się praca na roli, John powrócił do szkoły Mosesa Waddela. Szkoła ta odzyskała tymczasem swój dawny prestiż. Studiował tam m.in. grekę, łacinę, otrzymał typowe wykształcenie mieszkańca Południa.

W 1802 r. dwudziestoletni John wybrał się w długa, bo liczaca ponad 800 mil, drogę do New Haven w Connecticut, aby studiować w Yale College. Dlaczego akurat tam, nie zostało nigdy wyjaśnione, tym bardziej że mentalnie młody Calhoun, jako przedstawiciel Południa, powinien być raczej zbliżony w poglądach do republikanów Thomasa Jeffersona. Doskonale zaś wiedział, że uczelnią w Nowej Anglii zarządza żarliwy oponent polityczny Jeffersona, federalista Timothy Dwight. Wydaje się, że Yale wybrał świadomie, gdyż ta słynęła $z$ bardzo wysokiego poziomu i „dobrej ręki” Dwighta w wyborze kadry nauczającej. Studia ukończył we wrześniu 1804 r. Został wybrany do elitarnego Phi Beta Kappa. Nadmienić należy, że w czasie studiów w Yale pozostawał pod dużym wpływem Timothy'ego Dwighta. Niewatpliwie przekazywane przez niego poglądy polityczne w dużej mierze wpłynęły na późniejsza postawę Calhouna.

Wakacje spędził u wdowy po swym kuzynie, byłym senatorze Johnie Ewingu Colhounie. Ta część rodziny używała dawnej formy pisowni nazwiska przez „o”, a nie „a”. Czas wakacji w Newport w stanie Rhode Island należał do bardzo miłych. Tam spotkał też, wówczas 13-letnią, Floridę Colhoun. Po kilku latach została ona jego żoną ${ }^{7}$.

Po powrocie na Południe do Charlestonu podjał praktykę prawniczą u Henry'ego W. De Saussure. Ten liczacy się prawnik, w przekonaniach politycznych federalista, polecił Calhouna byłemu kongresmanowi $z$ Południowej Karoliny, a ówcześnie wpływowemu prawnikowi z Baltimore, Robertowi Goodloe Harperowi. Określił go jako człowieka majacego wiedzę znacznie przewyższająca wykształcenie jego rówieśników. Calhoun w lipcu 1805 r. znów pojawił się więc w Nowej Anglii i kontynuował naukę prawa. Udało mu się uzyskać stopień bachelora. Młody John Calhoun następny rok spę-

6 Cyt. za: M.D. P e ter s o n, The Great Triumvirate. Webster, Clay, Calhoun, New York 1987, s. 20.

7 Para doczekała się trzynaściorga dzieci, z których troje zmarło we wczesnym okresie życia. Por. http://en.wikipedia.org/wiki/John_C._Calhoun. 
dził w Litchfield w Connecticut. Tam studiował prawo (1805-1806) ${ }^{8}$. Ze studiów tych wyniósł bardzo pożyteczny nawyk. Studenci uczeni byli bowiem polegania na własnej pamięci, co przejawiało się tym, że przygotowywali notatki, uczyli się ich, ale przemawiali już bez zaglądania do nich. Tam również kształtował się jego późniejszy stosunek do Unii i władz federalnych. Margaret L. Coit, biografka Calhouna, uważa, że nie Południe, nie niewolnictwo, lecz uczelnie w Nowej Anglii wpłynęły na jego późniejsze poglądy nullifikacyjne9. Calhoun uzyskał wykształcenie prawnicze, jednak pociagała go kariera polityczna.

W 1806 r. powrócił zatem do Południowej Karoliny i został przyjęty do palestry w Charlestonie (1806-1808). Pracował w kancelarii znanego już sobie De Saussure'a. Jednak takie życie go przytłaczało. Ucieczka były codzienne trzymilowe samotne spacery, podczas których rozmyślał i zastanawiał się nad swym dalszym losem. W rok później przeniósł się do Abbeville, miejscowości położonej kilka mil od miejsca, w którym się urodził. Otworzył własna praktykę prawnicza, a ponadto był właścicielem farmy. Podobno prowadzenie farmy miał we krwi. Jakkolwiek prawnicy w Południowej Karolinie nie mieli zbyt dużo pracy u szkocko-irlandzkich farmerów, to Calhoun nie narzekał na brak zajęcia.

Mimo to szybko stracił wiarę w sens prowadzenia własnej kancelarii. Mogło to wynikać $z$ pewnego znudzenia prawem, ale najbardziej odzwierciedlało chyba jego cechy charakteru. Calhoun nie miał zupełnie poczucia humoru, nie przeklinał, nie pił, nie palił i nie żartował ${ }^{10}$. Był więc człowiekiem, którego zachowanie można by postrzegać albo jako wysoce dżentelmeńskie (by nie powiedzieć, $\dot{z}$ e tak wysublimowane, że aż nudne), albo jako depresyjne. Ratunkiem mogła być radykalna zmiana w życiu. Okazała się nią „ucieczka w politykę".

Incydent, do jakiego doszło 22 czerwca 1807 r., jak się okazało, odegrał tu rolę katalizatora. Brytyjski atak na amerykańska fregatę Chesapeake wzburzył Amerykanów ${ }^{11}$. Społeczność w Ab-

8 Szkoła w Litchfield została założona w 1774 r. przez sędziego Tappinga Reeve.

9 „Not the South, not slavery, but Yale College and the Litchfield Law School made Calhoun a nullifier". Por. M.L. C o it, John C. Calhoun, American portrait, Boston 1950, s. 42. Cyt. za: John C. Calhoun..., s. VIII.

10 M.D. Pet e r s o n, op. cit., s. 24.

11 Amerykańska fregata Chesapeake, dowodzona przez komandora Jamesa Barrona, została zaatakowana przez brytyjska fregatę Leopard. Brytyjczycy zażą- 
beville wymogła na Calhounie, jako prawniku, opracowanie patriotycznych rezolucji potępiających Brytyjczyków. Jakkolwiek nie zachowała się żadna $z$ nich, to $z$ pewnościa zyskały one uznanie wśród mieszkańców. Świadczy o tym wybór młodego Calhouna do zgromadzenia stanowego. Od tego momentu, aż do końca życia John C. Calhoun będzie związany $z$ polityka.

Jesienia 1808 r. został członkiem legislatury stanowej w Południowej Karolinie, gdzie reprezentował swych rodaków przez dwie sesje, czyli do 1809 r. Wygrał w wyborach do Kongresu i w rok później był już kongresmanem w Waszyngtonie12. Miał wówczas zaledwie 28 lat. Został wybrany $z$ ramienia partii demokratycznorepublikańskiej. Pamiętać jednak należy, że mentalność Calhouna jako przedstawiciela stanów Południa została znacznie zmodyfikowana przez lata nauki w Nowej Anglii. Raczej, sadzacc po postawie zajętej wobec incydentu $z$ fregata Chesapeake, należy ocenić go jako unionistę, czy może nacjonalistę, a nie reprezentanta wyłącznie regionalnych interesów Południa, tym bardziej że w przeciwieństwie do wytrawnych polityków $z$ partii demokratyczno-republikańskiej nie myślał wówczas o prawach stanowych i stanowej autonomii, nie był wprowadzony $\mathrm{w}$ tajniki ścisłego bądź szerokiego interpretowania Konstytucji ${ }^{13}$. Jedyne, co faktycznie mógł popierać, to rozwój rolnictwa. Oponenci polityczni, tj. coraz bardziej upadajacca partia federalistów, zdecydowanie bronili szerokiej interpretacji Konstytucji, wzmacniania władzy federalnej i stawiali na rozwój przemysłu oraz handlu. Jednak po „rewolucji 1800 r.” i wyborze republikanina Thomasa Jeffersona na prezydenta, byli zdecydowanie

dali oddania 4 marynarzy, uznając ich za zbiegów. Gdy dowódca statku odmówił, Brytyjczycy otworzyli ogień, zabijając 3, raniąc 18 marynarzy i zabierając 4 uznanych za dezerterów. Chesapeake przybiła do Norfolku, a wieści rozeszły się szybko, wzmagajac antybrytyjskie nastroje. W dniu 2 lipca prezydent Jefferson wydał proklamację nakazująca brytyjskim okrętom wojennym opuszczenie amerykańskich wód terytorialnych. W odpowiedzi Brytyjczycy wydali proklamację (17 X 1807) nakazujaca bardziej „vigorous prosecution of impressment of British subjects from neutral vessels". Por. Encyclopedia of American History, wyd. VII, eds J.B. Morris and R.B. Morris, chief consulting editor H.S. Commager, New York 1996, s. 154.

12 „It was later said that his was the only great reputation in the state during the antebellum years..." Cyt. za: M.D. P e te r s o n, op. cit., s. 25.

13 John Quincy Adams opisywał Calhouna jako polityka „above all sectional and factious prejudices more than any other statesman of his Union with whom I have ever acted". Cyt. za: The Nullification Era. A Documentary Record, ed. W.W. Freechling, New York 1967, s. 1. 
w opozycji, a władza w państwie należała do republikanów. W czasie, gdy Calhoun został kongresmanem prezydenturę sprawował kolejny republikanin James Madison, drugi z tzw. dynastii wirgińskiej (1809-1817). Jednak Calhoun dopiero kształtował swe poglądy i to $\mathrm{w}$ kierunku, jaki zapoczątkowali federaliści, dążąc do utrwalenia i scementowania federalnej Unii. Stanowy partykularyzm zdecydowanie nie należało do kręgu jego ówczesnych zainteresowań politycznych. Młody polityk zają postawę unionisty, a wkrótce wydarzenia zwiazane $z$ wojna $1812-1814 \mathrm{r}$. utwierdzily go w postawie nacjonalistycznej. Należy przy tym zaznaczyć, że ówczesny nacjonalizm amerykański miał cechy wyłącznie pozytywne. Dażył do ujednolicenia i wzmocnienia Unii, stworzenia jednego narodu, spotegowania poczucia dumy narodowej i pozytywnych wartości, jakie przyniosła zarówno pierwsza, jak i tzw. druga wojna o niepodległość.

O tej postawie niewatpliwie świadczy pierwsze przemówienie Calhouna w Izbie Reprezentantów wygłoszone 19 grudnia 1811 r. ${ }^{14}$ Przeciwstawił się w nim polityce ekonomicznej „virgińskich prezydentów", która - jego zdaniem - niszczyła amerykańska gospodarkę: „Jest jedna rzecz, która uczyni nas wielkim narodem [People przyp. J.A.D.], to produkcja; to nie forma, ale prawdziwy duch Unii; [...] każdy obywatel ma czuć poparcie rządu, [...] wówczas osiagnie siłę i bogactwo. Ochrona [protection - przyp. J.A.D.] i patriotyzm wzajemnie na siebie oddziałują. To jest właśnie droga, która wiedzie narody do wielkości"15.

W tym też czasie otrzymał mała plantację nad rzeką Savannah i ożenił się ze swą, wówczas 18-letnią, piękną i bogatą kuzynką Floride Bonneau Colhoun ${ }^{16}$. Ślub odbył się w styczniu 1810 r. w Bonneau's Ferry niedaleko Charlestonu. Niewatpliwie małżeństwo to zapewniło Calhounowi jeszcze mocniejsza pozycje społeczna i finansowa w Południowej Karolinie.

Kariera Calhouna w Izbie Reprezentantów trwała do roku 1817. Był bardzo dobrym organizatorem i świetnym mówca. Już w $1811 \mathrm{r}$. został przewodniczacym Komitetu Spraw Zagranicznych. Wtedy,

14 Calhoun zdecydował się rozpocząc swą polityczna karierę wraz z początkiem obrad 20. Kongresu, czyli po 14 miesiacach od wyboru.

15 Cyt. za: M.D. P e te r s o n, op. cit., s. 26.

16 Floride Bonneau Calhoun była potomkinia hugenotów, posażna i piękna panna z Charlestonu. Por. J.M. H e r n o n, Profiles in Character. Hubris and Heroism in the U.S. Senate, 1789-1990, New York 1997, s. 40. 
wraz z Henry Clay'em, jako żarliwy War Hawks optował za wojna z Wielka Brytanią ${ }^{17}$. Stany Zjednoczone rozpoczęły ja w 1812 r. To właśnie Clay, jako Speaker w Izbie Reprezentantów, umieścił Calhouna w Komitecie Spraw Zagranicznych, a wkrótce nowo mianowany sam objał funkcję Speakera. Podobnie, jak i inni politycy młodego pokolenia był przekonany, że najlepsza obrona interesów amerykańskich jest atak ${ }^{18}$. Uważał, że Amerykanie, urodzeni na wolnej ziemi, musza walczyć o zachowanie tego, co wywalczyli ich ojcowie. Maja do tego zarówno prawo, jak i - przede wszystkim obowiazek. Przejawiał w tym czasie skrajnie nacjonalistyczne poglądy.

Calhoun uważany był przez członków Kongresu za „Herkulesa, który dźwiga ciężar wojny na swych barkach”19. Ta sława znacznie ułatwiła mu dalsza karierę polityczną. Po zakończeniu wojny, w 1816 r. dał się znów poznać jako nacjonalista, gdyż poparł ustawę o cłach (Tariff of 1816), uważając ja za korzystna dla ekonomicznego rozwoju państwa ${ }^{20}$. Popierał protekcjonizm uważając, że rozwój przemysłu powinien objąć także dotychczas tylko plantatorskie Południe. Ideologia splatała się $z$ ekonomia. W celu ochrony przed brytyjskim przemysłem, amerykańskie państwo potrzebowało zabezpieczena i wsparcia dla rodzimej produkcji. Dlatego pomysł wprowadzania ceł ochronnych padał na bardzo podatny grunt.

Swe nacjonalistyczno-protekcjonistyczne poglądy przedstawił także w mowie, w której zainicjował dyskusję nad wprowadzeniem Bonus Billu. Wygłosił ją w Izbie Reprezentantów 4 lutego 1817 r. Mówił o potrzebie zastosowania ceł ochronnych, rozwoju przemysłu, budowy systemu dróg i kanałów łączących Wschód i Południe

\footnotetext{
17 Wspierali go przede wszystkim Henry Clay jako Speaker oraz kongresmeni William Lowndes i Langdon Cheves z Południowej Karoliny.

18 „We have said, we will change; we will defend ourselves by force”. Cyt. za: M.D. P e ter s o n, op. cit., s. 4.

19 Wyrażenia tego użył ponoć gubernator Nowego Jorku Thomas P. Grosvenor. Faktycznie Calhoun powoływał oddziały wojskowe, organizował fundusze, zajmował się logistyką, kontrolował walutę i handel.

${ }^{20} \mathrm{Cla}$ z 1816 r. podnosiły stawkę podatkową o 20\%. Dla Północy było to za mało. Daniel Webster, reprezentujac interesy Nowej Anglii, krytykował wprowadzenie tych ceł. Rynek amerykański był ewidentnie uzależniony od przemysłu Wielkiej Brytanii. Nacjonaliści dostrzegali ten problem i starali się mu zapobiec, przede wszystkim dążąc do rozwinięcia przemysłu amerykańskiego. Więcej na ten temat por. J.A. D a s zyńs ka, Stany wobec polityki rzadu federalnego Stanów Zjednoczonych Ameryki lat 1798-1830, Łódź 2004, s. 180-181.
} 
z Zachodem ${ }^{21}$. Nowe połączenia lądowe i wodne miały $z$ jednej strony wzmacniać wciąż rozszerzające swe terytorium państwo oraz ułatwić rozwój gospodarczy, ale powinny służyć zarazem celom strategicznym, co sam zaobserwował w czasie niedawnej wojny $z$ Wielką Brytanią. Może dlatego, przedstawiając ów bill, wspominał o swej miłości do kraju i o obowiązku, jaki nakłada na niego rola kongresmana ${ }^{22}$. W proponowanym projekcie dążył do wytworzenia więzi między poszczególnymi stanami Unii. Uważał, że umożliwiłyby one wszystkim stanom poczucie przynależności do silnego politycznie i ekonomicznie państwa. Równocześnie ostrzegał, że państwo bez drożnego systemu połączeń lądowych i wodnych utraci kontrolę nad swoimi obszarami. Nalegał zatem, aby szybko przyjąć ustawę dotycząca budowy dróg i kanałów. W swych oczekiwaniach bardzo liczył na Kongres, którego rolę wysoko cenił.

Bonus Bill przeszedł w obu izbach Kongresu ${ }^{23}$. Został jednak zawetowany przez prezydenta Jamesa Madisona w ostatnim dniu jego urzędowania (3 marca 1817 r.). Jakkolwiek popierał on protekcjonistyczna politykę państwa, to ze względów odnoszących się do interpretacji Konstytucji, która jako jej „Ojciec” współtworzył, uważał, że Bonus Bill narusza jej postanowienia. W uzasadnieniu utrzymywał, że „prawo regulowania handlu pomiędzy poszczególnymi stanami nie oznacza prawa budowy dróg i kanałów"24. Twierdził, że przy budowie dróg $z$ własnych środków Unia ma być zdana na zezwolenie stanu, przez który przechodzić miała droga. Proponował jednocześnie uzupełnienie Konstytucji o stosowną poprawkę, aby faktycznie móc wdrożyć system budowy dróg i kanałów. Bez wprowadzenia poprawki, według Madisona, budowa dróg i kanałôw, jako nie przyznana konstytucyjnie Kongresowi, leżała w kom-

21 "Good roads and canals, judiciously laid out, are the proper remedy"; "roads and canals add to the strength of the country”. Cyt. za: J o h n C. Ca lhou n, Roadways and Waterways, [w:] The Annals of America, vol. IV (17971820), Chicago-London-Toronto 1976, s. 458-459.

22 „Uninfluenced by any other considerations than love of country and duty [...] Every portion of the community - the farmer, mechanic, and merchant - will feel its good effects; and, what is of the greatest importance, the strength of the community will be augmented, and its political prosperity rendered more secure". Cyt. za: John C. Cal h o u n, Roadways..., s. 461.

${ }^{23}$ W Izbie Reprezentantów przeszedł stosunkiem głosów 86:84, a w Senacie 20:15. Por. J.A. D a s z yń s k a, op. cit., s. 184.

24 Cyt. za: ibidem, s. 185. Por. też J. M a d i s o n, Veto Message, 3.03.1817, [w:] The Forging of American Federalism. Selected Writings of James Madison, ed. S.K. Padover, New York 1965, s. 197. 
petencji stanów. Uważał, że decyzje, w formie ustawy, winny należeć do Kongresu, ich wykonanie zaś, tj. właściwa budowa, spoczywała już na barkach stanowych zgromadzeń ustawodawczych. Przypomnę, że 10 lat wcześniej, w Raporcie o drogach, Albert Gallatin proponował zbudowanie w państwie sprawnego systemu dróg i kanałów.

$Z$ tych powodów Madison nie poparł Bonus Billu, uważając że Calhoun nadinterpretuje Konstytucję. Stanowisko prezydenta podtrzymywało znaczenie 10. poprawki do Konstytucji, uzasadniało przestrzeganie praw stanowych i nie dopuszczało do rozszerzenia władzy Kongresu na sfery nie należące dotąd do jego kompetencji. Zatem przyznał rację Calhounowi, co do intencji jego pomysłu, ale zahamował wejście projektu ze względów na kwestię istotniejsza, tj. poszanowania słów Konstytucji. Posunięcie takie niewątpliwie negatywnie wpłynęło na inicjatywę ustawodawczą Calhouna.

$Z$ Izby Reprezentantów trafił on do ścisłej ekipy władzy wykonawczej, gdyż w gabinecie kolejnego prezydenta Jamesa Monroe pełnił funkcję sekretarza wojny (1817-1825). Trzeba przyznać, że udało mu się uporządkować kwestie militarne w Stanach Zjednoczonych $^{25}$. Armia i marynarka zostały znacznie zmodyfikowane. Ponadto należy podkreślić, że był wówczas najmłodszym członkiem gabinetu, gdyż miał zaledwie 35 lat. Mimo młodego wieku został wkrótce uznany za „Ojca departamentu wojny”. Odznaczał się wielką skutecznością i talentami organizatorskimi.

Trzykrotnie stawał do wyborów prezydenckich, w latach 1820 , 1824 i $1828^{26}$. Rola prezydenta miała być kolejnym i zarazem kul-

25 Nakazał m.in., aby posterunki wojskowe prowadziły dokładne zapisy dotyczące chorób i statystyki na temat populacji, pogody i handlu. Nieco szyderczo określił jego działania John Randolph, mówiąc, że był to najlepszy „kandydat armii na prezydenta”. Por. J. M a d i s o n, Veto Message..., s. 197.

26 Do wyborów w 1824 r. stanęli trzej najbliżsi współpracownicy prezydenta Jamesa Monroe: sekretarz stanu - John Quincy Adams, sekretarz skarbu - William Crawford, sekretarz wojny - John C. Calhoun. Oprócz nich kandydowali również Henry Clay i Andrew Jackson. Prezydent Monroe nie miał szans, o czym świadczy wypowiedź H. Claya: „Mr. Monroe has just been reelected with apparent unanimity, but he has not the slightest influence in Congress. His career was considered as closed. There was nothing further to be expected by him or from him". Cyt. za: J.M. He rnon, op. cit., s. 30. Por. też stronę http://www.infoplease.com/pa/ A0781450.html zawierająca zestawienie poszczególnych lat wyborów, nazwisk kandydatów, partii i otrzymanych głosów elektorskich. Wynika z nich, że Calhoun zarówno w 1824, jak i 1828 r. zdobył zdecydowaną przewage głosów w stosunku do swych rywali. 
minacyjnym punktem jego politycznej kariery. Za pierwszym razem przepadł zupełnie i pozostał nadal sekretarzem wojny w gabinecie Jamesa Monroe. Kolejne wybory wygrał John Quincy Adams (1825-1832), który za drugiej kadencji prezydenckiej Jamesa Monroe był sekretarzem stanu. John C. Calhoun został wówczas wybrany wiceprezydentem Stanów Zjednoczonych. Funkcję tę pełnił w latach 1825-1829. W kolejnych wyborach także startował. Jednak ponownie przypadło mu stanowisko wiceprezydenta (1829-1832), prezydentem został Andrew Jackson (1829-1837). To właśnie w czasie pierwszej kadencji Jacksona nastapił punkt zwrotny w karierze Calhouna. W 1832 r., tj. rok przed upływem kadencji, zrezygnował $z$ dalszego pełnienia swych obowiązków. Było to wówczas i jest do dnia dzisiejszego politycznym precedensem.

Wraz $z$ odejściem $z$ tak reprezentacyjnego stanowiska, a niewątpliwie też znaczącego, choćby w przypadku ostatecznej decyzji $\mathrm{w}$ razie równowagi $\mathrm{w}$ głosowaniach $\mathrm{w}$ Senacie, nastapiła diametralna zmiana jego wizerunku politycznego. $Z$ żarliwego nacjonalisty stał się gorącym rzecznikiem praw stanowych. Nie było to jednak odwrócenie się od Unii i wyłączne popieranie stanów Południa. Można powiedzieć, że raczej reprezentował teraz sprawę mniejszości, pojmowaną wówczas jako zagrażającą istnieniu nierozerwalnej Unii, a więc oceniana, $z$ punktu widzenia Waszyngtonu, jako negatywną.

Błyskotliwa kariera polityczna Johna C. Calhouna stanowiła wykładnię jego życiowego credo. Kwestie wagi państwowej były dlań najważniejsze. Zarówno jako kongresman, jak i członek władz egzekutywy dbał o interesy Stanów Zjednoczonych jako nierozerwalnej Unii. Jednak po rezygnacji $z$ wiceprezydentury, jak wspomniałam, całkowicie zmienił swój dotychczasowy punkt widzenia. Bronił praw stanowych nie tylko w Południowej Karolinie, ale również na forum ogólnopaństwowym, gdyż w roku 1833 został senatorem reprezentujacym w Kongresie interesy Południowej Karoliny. Funkcje tę pełnił aż do 1844 r. Niemal natychmiast, bo w tym samym roku, został sekretarzem stanu, obejmując ów urząd po tragicznej śmierci Abla P. Ushura. Obowiazki te sprawował tylko przez rok, tj. do końca prezydentury Johna Tylera. Mimo tak krótkiego czasu udało mu się doprowadzić do aneksji Teksasu. W roku 1845 znów został senatorem. Był nim aż do śmierci, zmarł w Waszyngtonie w dniu 31 marca 1850 r. ${ }^{27}$

27 Pochowany został w kościele p.w. św. Filipa w mieście Charleston leżącym w Południowej Karolinie. 
Przez 26 lat, czyli przez większość swego „politycznego” życia, John C. Calhoun był nacjonalista i unionistą. Ten nacjonalizm należy jednak rozumieć jako poglądy pozytywne, bo dotyczyły, podobnie jak poglądy unionistów, silnej władzy państwowej sprawowanej nad cała unią federalną. Przeciwne były separatystycznym teoriom, które wyrosły na bazie praw stanowych. Te jednak również przez długi czas nie miały na celu rozerwania Unii, lecz zapewnienie praw stanom, które odczuwały niedogodności odgórnej polityki federalnej. Prawa stanowe sięgały poczatków praw kolonialnych zagwarantowanych w kartach praw i przywilejów każdej brytyjskiej kolonii w Ameryce Północnej. Wykształciły się na bazie interpretacji dziewiątej i dziesiątej poprawki do Konstytucji28. Były elementem konstruktywnym dla państwa, gdyż wzmacniały poczucie stanowej kontroli wobec decyzji władz federalnych. Jednak, $z$ drugiej strony, stawały się czasem elementem destrukcyjnym, gdyż poprzez głoszenie nullifikacji i secesji zagrażały istnieniu jednej i nierozerwalnej Unii. Zarówno politycy w Waszyngtonie, jak i politycy stanowi nie umieli rozwiazać narastajacych problemów w państwie, zawierając powierzchowne kompromisy i nie ustępując właściwie wcale ze swoich poglądów. Przy czym należy zaznaczyć, że walka o prawa stanowe była odpowiedzią na politykę federalną, godząca w interesy poszczególnych części państwa, zwłaszcza od lat trzydziestych XIX w., w interesy plantatorsko-niewolniczego Południa. Wówczas pojawiły się głosy nawołujące do wyjścia z Unii, gdyż ta nie zabezpiecza ich interesów. Kwestie owe stanowiły ważny i palący problem Stanów Zjednoczonych, który „eksplodował” w postaci wojny secesyjnej.

Przypomnieć należy, że funkcjonowanie państwa normowała Konstytucja federalna z 1787 r. Dołaczone do nich w 1791 r. poprawki, znane jako Bill of Rights, oprócz wprowadzenia i zapewnienia swobód obywatelskich, uzupełniały również zasady współpracy między państwem a stanami. Mówiły o tym dwie ostatnie poprawki. Były jednak tak enigmatyczne, że zarówno stany $z$ jednej strony, jak i państwo $z$ drugiej, mogły je odmiennie interpretować. Ogólnie jednak Konstytucja wzmocniła Unię, podporządkowując politykę stanów polityce państwa - państwo zyskało nadrzędna pozycję wobec stanów. Wspólpraca między państwem a stanami układała się mniej lub bardziej pomyślnie, w zależności od

${ }^{28} \mathrm{Na}$ temat genezy praw stanowych por. J.A. Da s zyńs ka, op. cit., s. 4765. 
stopnia ochrony interesów poszczególnych stanów Unii. Swe niezadowolenie $z$ polityki federalnej okazywały zarówno stany północne, jak i, w późniejszym okresie, południowe. Te, odczuwając negatywne skutki państwowego protekcjonizmu, a zwłaszcza systemu wprowadzanych cel, reagowały negatywnie na ekonomiczna politykę państwa. Przywódczą rolę w stanach południowych przyjęli politycy z Południowej Karoliny. Krytykowali decyzje wzmacniajace państwowy protekcjonizm, pisali petycje i rezolucje czy też wysyłali delegatów do Kongresu, używali nawet gróźb, mówiąc o możliwości secesji, jednak ich głosy niewiele zmieniały decyzje Waszyngtonu. Zawierane kompromisy, choć co prawda łagodziły sytuację, nie eliminowały zasadniczych przyczyn konfliktów.

Zastanawiające jest jednak, co spowodowało tak gwałtowna i nieodwracalna zmianę poglądów politycznych Johna C. Calhouna? Dlaczego nie dotrwał nawet do końca swego urzędowania, lecz $\mathrm{w}$ rok przed zakończeniem kadencji demonstracyjnie zrezygnował? W amerykańskiej historiografii nazwisko Calhouna łaczone jest z nullifikacja, separatyzmem stanowym, secesja i prawami stanowymi, których stał się żarliwym obrońcą. Raczej nie pamięta się o Calhounie nacjonaliście i orędowniku wzmacniania Unii federalnej. Stał się więc symbolem negatywnym, politykiem dążącym do secesji, a zatem rozerwania Unii. Nie wspomina się 26 lat prounijnej polityki, lecz wyolbrzymia się 18 lat jego opozycji wobec polityki Waszyngtonu. Nie podkreśla się też jego nienagannych manier, wspaniałego stylu wypowiedzi, zaangażowania w temat, przekonania o słuszności bronionych racji i wielkiego uroku osobistego. Wydaje mi się to nazbyt krzywdzace w stosunku tej postaci 29.

Kolejnym pytaniem badawczym jest to, czy faktycznie jego reorientacja polityczna nastapiła dopiero w 1832 r., czy też należy jej źródeł szukać wcześniej?

Jak wspomniałam, w 1816 r. Calhoun poparł politykę podatkową państwa. Wspierał też tzw. Kompromis Missouri oraz System Amerykański wprowadzony przez Henry'ego Claya w 1824 r. ${ }^{30}$ Jed-

${ }_{29}$ Bardzo wyważony pogląd prezentuje amerykański historyk Charles Wiltse, który napisał prace o Calhounie jako nacjonaliście (1944 r.), nullifikatorze (1948 r.) i sekcjonaliście (1951 r.): „Though he is known today primarily for his sectionalism, Calhoun was the last of the great political leaders of his time to take a sectional position - later than Daniel Webster, later than Henry Clay, later than Adams himself". Cyt. za: http://en.wikipedia.org/wiki/John_C.Calhoun.

30 Cieszył się bardzo dobrą opinią Johna Quincy Adamsa, który w 1821 r. wypowiadał się o nim nader pozytywnie: „Calhoun is a man of fair and candid mind, 
nak w roku 1827 sprzeciwił się cłom, jakie miały być nałożone na wełnę i wyroby wełniane. Okazało się, że pomysł Claya dotyczący wdrożenia systemu wewnętrznego rynku i rozwoju narodowego przemysłu nie we wszystkim się sprawdził. W północno-wschodnich częściach Stanów Zjednoczonych, gdzie rozwinięty był przemysł wełniany, domagano się wprowadzenia dodatkowych ceł na wełnę i wyroby wełniane. W dniu 10 stycznia 1827 r. został przedstawiony bill wprowadzający 3 minimalne wyceny na produkty wełniane. Przewidywał też właściwie zakaz importu tych towarów. Bill przeszedł w Izbie Reprezentantów tego samego dnia. Następnym etapem było głosowanie w Senacie. Tam głosy „za” i „przeciw” rozdzieliły się równomiernie. W takiej sytuacji decyzja należała do wiceprezydenta, będącego jednocześnie przewodniczącym Senatu. Funkcje te sprawował John C. Calhoun. To jego głos „przeciw” zadecydował o odrzuceniu billu.

Nieprzyjęcie billu na krótko zahamowało ruch w kierunku wprowadzenia wyższych podatków. Konwencja w Harrisburgu (30 lipca - 3 sierpnia), położonym w stanie Pensylwania, zdominowana przez tych, którzy swe interesy opierali na wełnie, zgromadziła ponad 100 delegatów z 13 stanów. W uchwalonym memoriale do Kongresu nawoływali oni do ustanowienia zasady minimalnej wyceny wyrobów tekstylnych, proponując dodatkowo ustanowienie ceł na konopie, len, obrobione sztaby żelaza, stal i inne dobra. Memoriał ten został przedstawiony w Kongresie w dniu 24 grudnia $1827 \mathrm{r}$. Południe, uzależnione od światowego rynku na swe wyroby rolnicze, wystapiło jednak przeciw cłom protekcyjnym. Oznaczało to jednocześnie wzrost cen na produkty przemysłowe.

Południowa Karolina, której ekonomia opierała się w wielkim stopniu na uprawie bawełny, gdzie ponadto skutki „Paniki 1819 r.” utrzymały się znacznie dłużej niż na Północy, stanęła na czele walki z protekcjonizmem państwowym. Mowa Thomasa Coopera wygłoszona 2 lipca 1827 r. w Kolumbii, w stanie Południowa Karolina, wymierzona była w ekonomiczna polityke państwa faworyzującego głównie Północ. Protekcjonistyczna polityka Waszyngtonu była zagrożeniem dla Południa, które zaczęło kalkulować wartość unii federalnej, coraz dobitniej głosząc konieczność jej opuszczenia.

of honorable principles, of clear and quick understanding, of cool self-possession, of enlarged philosophical views, and of ardent patriotism. He is above all sectional and factious prejudices more than any other statesman of this Union with whom I have ever acted". Cyt. za: http://en.wikipedia.org/wiki/John_C.Calhoun. 
Jednak polityka protekcjonizmu państwowego popierana była przez przywódców Kongresu. Nowe cła protekcyjne zatem nałożono. Zostały one uchwalone 19 maja 1828 r. przez 20. Kongres. Były to tzw. Tariff of Abominations, czyli Cła Odrazy ${ }^{31}$. Właśnie one doprowadziły do gwałtownych wystapień przeciwko ich nałożeniu i silnej opozycji południowych stanów. Wyjaśnijmy tu genezę stanowych protestów. Były one odpowiedzia na prowadzona politykę federalna, która miała wzmacniać i scalać Unię, jak w przypadku Systemu Amerykańskiego, która jednak nie zawsze leżała w interesie poszczególnych jej stanów członkowskich. Nie wdając się w głębszą analizę należy powiedzieć, że u źródeł konfliktu leżały zarówno kwestie polityczne, jak i ekonomiczne. Unia, miast się scalać, coraz bardziej ujawniała rozłam między silnie rozwiniętymi pod względem handlowym i przemysłowym stanami Północy, a niewolniczo-plantatorskim Południem. Cła zapowiedziane w 1828 r. uderzały ekonomicznie w stany południowe. Były $z$ kolei korzystne dla Nowej Anglii, gdyż podtrzymywały protekcjonizm, podobnie wyglądała sprawa na farmerskim Zachodzie. Zresztą demokraci, którzy wprowadzali te cła, czynili to właśnie $z$ chęci pozyskania Zachodu w wyborach prezydenckich, w których ich kandydatem był Andrew Jackson. Południe po raz kolejny odczuło więc skutki faworyzowania Północy. Dla jego mieszkańców cła oznaczały „konieczność kupowania niezbędnych wyrobów gotowych na zamkniętym rynku i po zawyżonych cenach" 32 . Cła, zaaprobowane przez prezydenta Johna Quincy Adamsa, podnosiły bowiem opłaty głównie na towary sprowadzane $z$ Wielkiej Brytanii, $\mathrm{w}$ tym $\mathrm{m}$.in. na runo wełniane, rudę żelaza i wyroby żelazne, len, bawełnę, konopie i melasę. Podwyżka była znaczna, bo z 33 i 1/3 do połowy wartości towarów. Intencja wprowadzenia tak wysokich ceł była ochrona amerykańskich hodowców owiec i właścicieli kopalni. Jednak w ślad za wprowadzeniem ceł nie poszły decyzje wspierające rozwój strefy surowcowej Stanów Zjednoczonych. Podjęto natomiast ostra krytykę zarówno samych ceł, jak i polityki państwa. Doszło do niej także na Północy, gdyż cła okazały się niekorzystne i dla północno-wschodnich obszarów państwa. Ponadto politycy przeliczyli się w swych rachubach. Wielkim zaskoczeniem dla jacksonistów było poparcie dla ceł

31 Por. ibidem, s. 219-231.

32 J.C. Calh ou n, The South Carolina Exposition and Protest, 19 XII 1828, [w:] id e m, Union and Liberty. The Political Philosophy of John C. Calhoun [dalej: Exposition], ed. R.M. Lence, Indianapolis 1992, s. 313. 
udzielone przez Nową Anglię. Mimo że nie odpowiadały jej one zbytnio, to $z$ uwagi na kontynuacje polityki protekcjonistycznej, zostały przez nia poparte. Jacksoniści uważali, że właśnie ze względu na niekorzystne skutki dla Nowej Anglii, ta nie poprze ceł. Stało się jednak inaczej. Bill przeszedł w Izbie Reprezentantów w dniu 23 kwietnia stosunkiem głosów 105:94, a 13 maja w Senacie 26:21. Zwolennicy Jacksona ze stanów środkowych i z Zachodu głosowali za wprowadzeniem ceł, aby pozbawić poparcia zwolenników Adamsa i Claya w kampanii wyborczej. Trzeba mocno podkreślić, że cła były niewatpliwie elementem gry politycznej. John Randolph określił je jako nie tyle odnoszace się do jakiejkolwiek produkcji, lecz do wyprodukowania prezydenta ${ }^{33}$.

Przeciwko cłom szczególnie oponowało Południe, a najbardziej Południowa Karolina. Delegaci z tego stanu udali się nawet do Waszyngtonu, gdzie spotkali się $z$ senatorem Robertem Y. Hayne, reprezentującym w Senacie Południową Karolinę i będącym orędownikiem praw stanowych ${ }^{34}$. Po burzliwej dyskusji zgodzili się wstrzymać z protestami aż do czasów ogłoszenia wyniku wyborów prezydenckich, gdyż liczono, jeżeli już nie na odwołanie ceł, to przynajmniej na obniżenie ich stawek przez Jacksona.

John C. Calhoun nie wziął udziału w tymże spotkaniu, choć jego efekt był jak najbardziej po jego myśli. Był to taktyczny unik, gdyż większość polityków nadal uważała go za nacjonalistę. Sadzono tak, mimo iż jako przewodniczacy Senatu zagłosował przeciwko wprowadzeniu ustawy o wełnie w 1827 r. Zapewne nie dostrzeżono jeszcze wówczas początku jego politycznej transformacji. Zdajac sobie $z$ tego sprawę, nie chciał brać udziału w spotkaniu rozentuzjazmowanych delegatów.

Kiedy w dniu 21 października 1828 r. stało się oczywiste, że Andrew Jackson po pokonaniu Johna Quincy Adamsa został prezydentem, a wiceprezydentem ma być ponownie John C. Calhoun, natychmiast przystapiono do protestów przeciwko Tariff of Abominations, a właściwie do nullifikacji wprowadzającej je ustawy Kongresu. Płomienne przemówienie w tej kwestii wygłosił bogaty plan-

33 „The bill referred to manufactures of no sort of kind, but the manufacture of a President of the United States". Cyt. za: Encyclopedia of American History..., s. 187.

34 Robert Young Hayne (1791-1839) z Południowej Karoliny, senator w latach1823-1832, w latach 1832-1834 gubernator Południowej Karoliny, poplecznik H. Claya. Por. Dictionary of American History, eds M. Martin, L. Gelber, Paterson, New Jersey 1959, s. 278. 
tator i najbardziej wpływowy polityk z Południowej Karoliny, James A. Hamilton, jr. Poruszył wszystkie palace sprawy, jakimi dla Południa była polityka rządu federalnego, podatki, trwałość Unii, respektowanie praw stanowych i nullifikacja. Nowemu prezydentowi wykazał niezbicie, jakie szkody dla kraju niesie kontynuacja polityki protekcjonizmu państwowego. Ukazał wielkie rozgoryczenie Południa i jego desperację $\mathrm{w}$ obronie swych praw. Podkreślił olbrzymie zróżnicowanie między interesami Północy a Południa. Tym samym głosił oczywista, acz nadal nie przyjmowana w Waszyngtonie do wiadomości prawdę, że ustawy korzystne $z$ ekonomicznego punktu widzenia dla Północy sa niekorzystne dla Południa ${ }^{35}$.

Warto podkreślić, że James A. Hamilton, jr. zachowywał należny dystans do kwestii nullifikacji. Używał tego terminu dość często, ale było widoczne, że wejście jej w życie miało być tylko ostatecznością. Tymczasem był to rodzaj argumentu dla decyzji prezydenta Jacksona. Ponadto przemówienie nie kończyło się nawoływaniem do secesji, lecz wyrażało nadzieję na poprawę sytuacji Południa oraz wiarę $\mathrm{w}$ to, że wysiłki Ojców Założycieli nie zostana zaprzepaszczone.

Pojawiały się artykuły prasowe ukazujace ekonomiczny upadek Południa po wejściu w życie ceł z 1828 r., a stanowe legislatury opracowywały rezolucje sprzeciwiajacce się ustawie celnej. Legislatura Południowej Karoliny wydała 8 rezolucji uznających cła za niekonstytucyjne i niesprawiedliwe ${ }^{36}$. Najwięcej rozgłosu przyniosła The South Carolina Exposition and Protest. Jej autorem był wiceprezydent John C. Calhoun. Z pewnościa dlatego rezolucji tej nie podpisał swym nazwiskiem. Przedstawił w niej teorię suwerenności stanowej i uzasadniał doktrynę nullifikacji i secesji przez pojedynczy stan.

Południe zdawało sobie sprawę, że jego pozycja w Unii jest coraz słabsza. Protesty na niewiele się zdawały, gdyż w myśl postanowień Konstytucji federalnej, stany były podporządkowane decyzjom federalnym. Jeżeli zaś chodzi o podatki, to również z przyczyn zapisu konstytucyjnego miały być one jednolite dla całego obszaru państwa. Protesty stanów Południa nie przynosiły więc poprawy ich sytuacji, choć tamtejsi politycy wspierali je teoria praw stanowych

35 J.A. H a milt o n jr., Speech at Walterborough, 21 X 1828, [w:] The Nullification Era..., s. 50-61. Por. też J.A. D a s z y ń s k a, op. cit., s. 231-233.

36 J.M. H e r n o n, op. cit., s. 43. 
wysnutych na podstawie dziewiatej i dziesiatej poprawki do Konstytucji.

Dlatego stopniowo dochodzili oni do przekonania, że skoro Unia federalna nie zabezpiecza ich interesów, to jest ona dla nich niekorzystna. A skoro tak, to należałoby ja opuścić. Tłumaczono to tym, że skoro wejście poszczególnych stanów do Unii opierało się na zasadzie dobrowolności, gdyż było wynikiem głosowania w stanowych konwencjach konstytucyjnych, to również opuszczenie Unii może odbywać się na podobnych zasadach. Trzeba przyznać, że koncepcja ta była bardzo popularna wśród polityków stanów Południa. Liczyli oni również na to, że koncepcję tę uda przeforsować się w Senacie Stanów Zjednoczonych. Szykował się do jej przedstawienia reprezentujacy Południe i koncepcje praw stanowych senator Robert Y. Hayne $z$ Południowej Karoliny. Przeciw niemu stanał wytrawny orator strony federalnej senator Daniel Webster $z$ Massachusetts. Obaj byli $z$ wykształcenia prawnikami i doskonałymi mówcami. Achilles Południa toczył bój z Lwem Północy.

Debata, a właściwie debaty, gdyż było ich sześć, przeszły do kanonu przemówień politycznych $\mathrm{w}$ amerykańskim Kongresie ${ }^{37}$. Toczyły się pod koniec stycznia 1830 r. Senator Hayne bronił idei praw stanowych, opierajac się na koncepcji suwerenności stanowej. Jako ostateczność zaproponował zastosowanie nullifikacji. $Z$ kolei Daniel Webster, będący żarliwym orędownikiem jedności Unii i poszanowania słów Konstytucji, bronił praw federalnych i stał na stanowisku wzmacniania praw rządu federalnego. Można powiedzieć, że Południe popełniło tu taktyczny błąd, gdyż zamiast puścić mimo uszu kwestie konstytucyjne i rozbrat Wschodu z Zachodem, kurczowo broniło swych racji. Jego przedstawiciele byli bowiem całkowicie przekonani o słuszności swoich argumentów, w dodatku boleśnie odczuwali skutki federalnej polityki ekonomicznej. Północ, reprezentowana przez Webstera, niewattpliwie czerpała korzyści ze sterowanej przez siebie polityki federalnej. Bezkompromisowy ton wypowiedzi Webstera i siła jego argumentów dążyły do pokonania niezadowolonego Południa. Jeszce niedawno, bo podczas wojny 1812-1814 r., to stany Północy odczuwały niedogodności polityki federalnej i groziły secesja. Teraz, w roku 1830, by sytuacja diametralnie się zmieniła.

37 Robert Y. Hayne przemawiał w dniach 19, 21-25 i 27 I 1830, odpowiedzi udzielał Daniel Webster w dniach 20, 26 i 27 I. Por. J.A. D a s zyń s k a, op. cit., s. 253 . 
Debaty zakończyły się zwycięstwem koncepcji federalnych. Robert Y. Hayne przegrał. Wraz z nim przegrało Południe. Świadkiem tej porażki był również John C. Calhoun ${ }^{38}$. Klęska orędowników praw stanowych była także i jego klęską. Koncepcja ta przegrała $z$ nacjonalistyczno-federalistyczną wizją jedności Unii. Można powiedzieć, że gdyby Calhoun nie przeszedl do opozycji i popierania praw stanowych, byłby wygranym, a jego idea jedności Unii święcilaby tryumfy.

Rok 1830 przyniósł także pogorszenie stosunków między Calhounem a prezydentem Jacksonem. W kwietniu, $z$ okazji urodzin Jeffersona, został zorganizowany bankiet ku jego czci. To właśnie na nim doszło do poróżnienia obu polityków. Okazję ku temu dały wznoszone - aż 104 - toasty. Politycy $z$ południa i północy wyrażali w nich swoje poglądy polityczne. Zwłaszcza Południowcy szermowali słowami, że wobec niesprawiedliwych podatków uzasadniony jest opór wobec nich i nie jest to żadna zbrodnią. Pod koniec przyjęcia prezydent wzniósł toast za jedność unii: „Nasza Unia federalna musi być zachowana”. Wówczas wiceprezydent Calhoun odpowiedział toastem „Unia: najdroższa naszej wolności; pamiętajmy, że może być zachowana jedynie przez poszanowanie praw stanów i rozdzieleniu po równo korzyści i ciężarów [wynikających z przynależności do - przyp. J.A.D.] Unii" 39 .

W tym samym roku pojawiły się kolejne punkty zapalne między Calhounem a Jacksonem. Powodem stał się towarzyski ostracyzm. Od początku tego roku żona Calhouna, jako Second Lady, i kilka innych żon członków gabinetu Jacksona, zaczęło towarzysko bojkotować Peggy O’Neale. Jej rodzice byli właścicielami tawerny w Waszyngtonie, a ona pracowała tam niegdyś jako kelnerka. Była bardzo ładna i wykształcona, podobno dobrze grała na pianinie. Powszechnie wiadomo było jednak, że nie zachowała cnoty przedmałżeńskiej $z$ pierwszym mężem, a następnie pozostawała

38 J.C. Calhoun dostarczał kartki $z$ informacjami na temat tego, co Hayne ma powiedzieć. Dlatego ten przemawiał w imieniu swoim, stanów południowych i wiceprezydenta. Podnosiło to rangę debaty. Por. M.D. P e t e r s o n, op. cit., s. 175.

39 "Our Federal Union: It must be preserved” oraz „The Union: Next to our Liberty most dear; may we all remember that it can only be preserved by respecting the rights of the states and distributing equally the benefit and burden of the union". Treść toastów cyt. za: J.M. H e r n o n, op. cit., s. 43. Ponoć słyszano, jakoby Jackson dodał określenie „Our Union” zamiast „The Union” (Martin Van Buren, bedacy sekretarzem stanu), a nawet „Federal” (senator Robert Y. Hayne). 
w nieformalnym związu $z$ drugim. W dodatku wyszła za niego za mąż jeszcze w okresie żałoby. Jednak nie chodziło tu o jej dawniej wykonywana profesję i nieprzestrzeganie zasad moralnych, ale o fakt, że taka osoba, jako żona senatora Eatona, mianowanego w 1829 r. na sekretarza wojny, weszła w skład politycznej elity Waszyngtonu.

Wydaje się, że oboje nie pasowali do swych ról. Pan Eaton został nominowany na wspomniane stanowiso przez Jacksona dopiero wtedy, gdy odrzucił je sędzia Hugh L. White. Dodać należy, iż obaj panowie byli bardzo zaprzyjaźnieni $z$ prezydentem ${ }^{40}$. Natomiast Eaton nie miał poparcia wiceprezydenta Calhouna i pozostałych członków gabinetu ${ }^{41}$. Pani O’Neil Eaton zaś, oprócz swej dość wątpliwej przeszłości, odznaczała się niedelikatnością, złym charakterem i brakiem szacunku dla swego męża ${ }^{42}$. Lubiła też intrygi. Mimo to w obronę wzią ja prezydent, ale napięta sytuacja nie uległa zmianie $^{43}$. Pani Margaret (gdyż zmieniła formę imienia na bardziej

40 „You [sędzia White - przyp. J.A.D.] and Major Eaton were the only men with whom I had such acquaintance and intimacy that insured me my entire confidence were well placed..." Cyt. za: Andrew Jackson to Hugh L. White, Washington 9 IV 1831, [w:] Correspondence of Andrew Jackson, ed. J.S. Bassett, vol. IV, New York 1969 (reprint wydania $z 1927$ r.), s. 258.

41 „I was then ignorant of the fact that there existed among some of the members of the Cabinet an hostility to Major Eaton..." Cyt. za: Jackson's Case against Calhoun, February 1831, [w:] Correspondence of Andrew Jackson..., s. 235-236.

42 Podobno pierwszy maż pani O’Neil, 39-letni marynarz, za którego wyszła, gdy miała 17 lat, popełnił samobójstwo, wiedzac o romansie swej żony $z$ amerykańskim senatorem. Poznała go w 1818 r., gdy Eaton był 28 letnim wdowcem, a jednocześnie senatorem w Kongresie. Por. http://en.wikipedia.org/wiki/Margaret_O;Neil_Eaton oraz http://en.wikipedia.org/wikiPetticoat_affair, gdzie podane jest, że mąż marynarz zmarł na chorobę płuc. Jednak wersja o samobójstwie jest potwierdzona w encyklopedii stanu Tennessee: http://tennesseeencyclopedia.net/ imagegallery.php?EntryID=E008.

43 Świadczy o tym notatka sporządzona przez Andrew J. Donelsona, członka rodziny A. Jacksona (w roku 1791 Jackson poślubił Rachel Donelson Robards, a w roku 1794 ceremonia została powtórzona w majestacie prawa) na temat listu Pani Eaton do prezydenta, a prywatnie do swego wujka: „This letter is abundant evidence of the indelicacy which distinguishes her character, and is disgraceful to her husband. Instead of coming to me as the head of my family for explanations where objections to my conduct were entertained, they have invariably approached the President with childish importunities, first aiming to excite his sympathies, and then to pour upon them the poison which they had concocted for all who did not bow to her commands". Cyt. za: Appended note by A.J. Donelson to Jackson, 10 VI 1830, [w:] Correspondence of Andrew Jackson..., s. 145-146. 
dostojna) O’Neale była towarzysko bojkotowana ${ }^{44}$. Nawet rodzina prezydenta stosowała wobec niej obyczajowy ostracyzm, choć stopniowo topniał on na skutek jego nalegañ ${ }^{45}$. Wkrótce pozycja społeczna tej pani stała się sprawą polityczną ${ }^{46}$. Gdy maż bojkotowanej zwrócił się do gabinetu o pomoc, jedyną osoba, która udzieliła mu wówczas wsparcia, był sekretarz stanu Martin Van Buren (wówczas wdowiec). W ten sposób Van Buren wkupił się w łaski prezydenta Jacksona.

W istocie jednak Van Buren uważał, że „sprawa” z żona sekretarza wojny, jak i kwestia Seminolów, o czym dalej, naraża na szwank administracje, zaproponował zatem prezydentowi swoja dymisję ${ }^{47}$. Wiosna $1831 \mathrm{r}$. dymisję złożyli również pozostali członkowie gabinetu, a wśród nich i Eaton. Jackson uznał Van Burena za godnego polityka i przyjaciela, po czym uczynił go najważniejsza osoba w partii demokratycznej. W rezultacie zreorganizowano rzad i pozbyto się zeń niewygodnego sekretarza wojny. Calhoun zaś naraził się na niełaskę prezydenta. Ich relacje były teraz bardzo napięte, wręcz „lodowate”. Eaton zaś został mianowany gubernatorem Terytorium Florydy (1834-1836), a następnie ambasadorem we Francji (1836-1840). W obu tych miejscach państwo Eaton byli towarzysko akceptowani i do żadnego skandalu obyczajowego nie doszło. Również, gdy wrócili w 1840 r. do Waszyngtonu nie przypominano sprawy sprzed kilku lat. Pan Eaton założył kancelarię prawnicza, która prowadził aż do śmierci w 1856 r. W trzy lata później Margaret „Peggy” Eaton, wówczas 59-letnia poślubiła 19-letniego

44 Dowodzi tego fakt, że Pani Eaton odmówiła przybycia na obiad, na który została zaproszona przez prezydenta A. Jacksona, gdyż, jak się wyraziła, „I could not expect to be happy at your house for this would to be expect a different course of treatment from part of your family [...] I have spoken of your family in no other manner than a respectful one. Much injustice as I think they have done me". Por. Mrs. Margaret Eaton to Jackson, Washington 9 VI 1830, [w:] ibidem, s. 145 .

45 Jesienią Andrew J. Donelson pisał w tej sprawie do Jacksona, że „wszyscy maja prawo do wyboru swego towarzystwa”. Por. A.J. Donelson to Jackson, Washington 26(?) X 1830, [w:] ibidem, s. 191.

46 Sam Jackson twierdził, że sprawa ta była tylko nikczemnymi oszczerstwami wobec Eatona: „to enable me to perceive the true case of the vile slanders against and cruel persecution of Major Eaton". Por. Jackson's Case against Calhoun, February 1831, [w:] ibidem, s. 236.

47 „Dear Sir, I feel it to be my duty to retire from the Office to which your confidence and partiality called me". Cyt. za: Secretary Van Buren to Jackson, Washington 11 IV 1831, [w:] ibidem, s. 260. 
nauczyciela muzyki i tańca pochodzacego $z$ Włoch ${ }^{48}$. Tak zakończyła się tzw. Petticoat affair (afera o spódniczkę).

Ponadto niemal w tym samym czasie, co Eaton affair pojawiła się druga sprawa: ujawniono korespondencję Calhouna z 1818 r., gdy był sekretarzem wojny, w której krytykował wojskowa kampanię Jacksona na Florydzie.

Wiosna 1830 r. Jackson dowiedział się, że Calhoun mocno nalegał, aby ukarać Jacksona za jego postępowanie wobec Seminolów w 1818 r. ${ }^{49}$ List zawierajacy te zarzuty został napisany przez Williama H. Crawforda, a upowszechniony przez Williama L. Lewisa i innych w celu zdyskredytowania Calhouna w oczach prezydenta. Dotychczas Jackson był przekonany, że w 1818 r. Calhoun go popierał. Zażądał więc wyjaśnień. W tym celu napisał list do Calhouna, dołączając doń kopię listu Crawforda. Nie krył swego zdziwienia, gdyż dotychczas był przekonany, że Calhoun całkowicie popierał jego politykę ${ }^{50}$. Kolejny list przesłał mu w niecałe dwa tygodnie później. List ów miał już zdecydowanie inny charakter. Jackson nie tyle żądał wyjaśnień, co zarzucał Calhounowi brak lojalności, dwulicowość i niszczenie reputacji prezydenta. Określił go nawet mianem Brutusa ${ }^{51}$. Przestał uważać Calhouna za człowieka godnego miana jego przyjaciela. Wszelkie wyjaśnienia uważał już za zbędne i wyraził życzenie, aby Calhoun „już nic do niego nie pisał w tej sprawie" 52 .

Wyjaśnienia Calhouna nie usatysfakcjonowały prezydenta. Sprawa powróciła w lipcu 1830 r., gdy prezydent napisał do Calhouna,

48 Wkrótce młody małżonek uciekł $z$ jej pieniędzmi i wnuczką. Por. http://americanhistory.suite101.com/article.cfm/the_petticoat_affair.

49 Korespondencja Johna C. Calhouna $z$ Andrew Jacksonem świadczy o zagrożeniu, jakie stanowili Indianie, ale Calhoun, jako sekretarz wojny, zalecał rozwagę i humanitarne postępowanie wobec Seminolów: „With this view you may be prepared to concentrate your forces and to adopt the necessary measures to terminate a conflict which it has ever been the desire of the President, from considerations of humanity, to avoid; but which is now mase necessary by their Settled hostilities". Por. Secretary Calhoun to Jackson, Department of War, 26 XII 1817, [w:] Correspondence of Andrew Jackson..., vol. II, s. 342.

50 Andrew Jackson to vicepresident Calhoun, Washington $13 \mathrm{~V}$ 1830, [w:] ibidem, vol. IV, s. 136.

51 "I repeat, I had a right to believe that you were my sincere friend, and, until now, never expected to have occasion to say to you, in the language of Caesar, Et tu Brute". Cyt. za: Andrew Jackson to vicepresident Calhoun, 30 V 1830, [w:] ibidem, vol. IV, s. 141.

52 Loc. cit. 
podtrzymując swoja poprzednią opinię, że ten „w pełni wyrażał poparcie dla prowadzonej przez Jacksona kampanii przeciw Seminolom" 53 .

$Z$ kolei Calhoun rozpowszechniał pamflet dotyczacy okrucieństw Jacksona wobec Seminolów (ukazał się 17 lutego 1831 r.). Odpowiedzią Jacksona było memorandum przeciwko Calhounowi. Prezydent wybielał się w nim, twierdzacc, że miał pełna zgodę ówczesnego prezydenta Jamesa Madisona i aprobatę Kongresu wyrażona „ustawami $z$ kwietnia i lipca 1812 r." 54 Ponadto cała odpowiedzialność zrzucał na Indian, Murzynów i zagranicznych, tj. angielskich agentów, którzy podburzali „bandyckich Indian i czarnych”55. Obarczał nią również Calhouna, którego wypowiedzi przytaczał, a z których niezbicie wynikało, że ten całkowicie popierał działania Jacksona ${ }^{56}$. Takie wzajemne oskarżanie się dawnych przyjaciół doprowadziło do zerwania między obu politykami, a w przyszłości do poparcia udzielonego przez Jacksona dla Van Burena, jako kolejnego prezydenta.

$\mathrm{W}$ dodatku latem $1831 \mathrm{r}$. wypłynęła jeszcze jedna sprawa. Był nia list $z$ Fort Hill (Fort Hill Address). To w nim Calhoun zawarl wykładnię swych poglądów uzasadniając konstytucyjne prawo stanów do nullifikacji ustaw Kongresu ${ }^{57}$. Odwołał się przy tym do Rezolucji Kentucky i Wirginii, w których Jefferson i Madison, jako pierwsi, uzasadniali prawo stanów do nullifikacji ustaw federalnych. Pisał, że „gdy nie istnieje prawo do wyrażania sprzeciwu, alternatywa może być albo poddanie się i ucisk $z$ jednej strony, albo zbrojny opór z drugiej" 58 . Nie nawoływał jednak do rewolucji, lecz do reformowania systemu ${ }^{59}$.

Rozbrat Calhouna $z$ polityka Andrew Jacksona i intrygami politycznymi ambitnego polityka, jakim okazać miał się Martin Van Buren nastapił definitywnie w 1832 r. Prezydent Jackson mianował

53 A. Jackson to vicepresident Calhoun, Hermitage 19 VII 1830, [w:] ibidem, s. 162.

54 Jackson's Case against Calhoun, February 1831, [w:] ibidem, s. 228.

55 Ibidem, s. 230.

56 Pisał m.in., że Calhoun informował go, iż „the evacuation was desired by the President to take place without force; but concludes by saying you are to understand, that if force should be ultimately necessary, that it should be resorted to". Te i podobne informacje por. ibidem, s. 231, 232-235.

57 The Fort Hill Address of John C. Calhoun, 26 VII 1831, http://pages.prodigy. net/krtq73aa/calhoun.htm.

58 Ibidem.

59 „Not in revolution or overthrow, but in reformation”. Cyt. za: ibidem. 
bowiem Van Burena ambasadorem w Wielkiej Brytanii. Głosowanie w Senacie przyniosło równowagę, wobec tego Calhoun, korzystając $z$ prawa przysługującemu przewodniczącemu Senatu, odegrał się na swym adwersarzu i zagłosował przeciw nominacji. Miało to, jego zdaniem, zakończyć polityczna karierę Van Burena. Nadzieje te nie ziściły się jednak.

Rok 1831 był przełomowy dla umocnienia Calhouna w przekonaniu, że stoi po niewłaściwej stronie barykady. Ten człowiek o niezłomnych zasadach, zdajac sobie sprawę z politycznych intryg w otoczeniu Jacksona, odczuwając je również na własnej skórze, widzac niejednoznaczna postawę prezydenta w wielu kwestiach, a także coraz bardziej rozumiejąc niezadowolenie stanów Południa z federalnej polityki państwa, przechodził do politycznej opozycji, popierajac prawa stanów do nullifikacji. Zerwanie nastapiło w rok później, jednak jego korzeni należy szukać już w zmianach, jakie następowały w polityce państwa od końca lat dwudziestych XIX w., a które, jako negatywne dla interesów Południa, zaczą wreszcie dostrzegać Calhoun (jego weto w sprawie Woolens Bill). Dalsze wprowadzanie protekcjonizmu państwowego, korzystnego jedynie dla pewnych części Unii, skoncentrowane w Tariff of Abominations, przyniosło reakcję Calhouna w postaci jego politycznego pamfletu pod tytułem South Carolina Exposition and Protest, w którym zdecydowanie bronił praw Południa. Gdy wybuchł obyczajowy skandal z Panią Eaton, polityczny z Seminolami, ponadto padła propozycja dymisji gabinetu wymyślona przez Van Burena i zbliżały się wybory prezydenckie, na wygranie których Calhoun, dyskredytowany przez Jacksona i Van Burena, nie miał żadnych szans, umocnił się w przekonaniu o konieczności poparcia praw stanowych. Rozczarowanie polityka państwa skłoniło go zatem do poszukania nowej politycznej roli jako wyraziciela polityki stanów Południa.

Wybory prezydenckie w listopadzie 1832 r. przyniosły duże przetasowania polityczne, o czym doskonale wiedzieli zarówno Jackson, Van Buren, jak i Calhoun. Narodowo-demokratyczna Konwencja (The Democratic National Convention) w Baltimore ponownie nominowała Jacksona na prezydenta, ale na wiceprezydenta nominowano Van Burena zamiast Calhouna. W takiej sytuacji, w dniu 28 grudnia $1832 \mathrm{r}$. Calhoun zrezygnował $\mathrm{z}$ pełnienia urzędu. Jakkolwiek oceniany jest jako zwolennik nullifikacji i secesji, to jednak w 1957 r. Senat USA uznał go za jednego $z$ pięciu najwybitniejszych senatorów w historii Stanów Zjednoczonych. 